\title{
FLEXIBILITY OR INSECURITY? WOMEN'S EXPERIENCES OF FIXED-TERM RESEARCH-ONLY POSITIONS IN THE ACADEMY
}

\author{
Josie M. Roberts \\ Roy McKenzie Centre for the Study of Families \\ Victoria University of Wellington
}

\begin{abstract}
An increased use of fixed-term contracts and a separation between teaching and research are symptomatic of shifts in the organisation of academic labour internationally. Debate has surfaced as to whether such changes associated with new managerialism offer opportunities to women or intensify their enduring disadvantage in the academy. Researchonly staff present a particularly interesting case: women appear to be relatively successful in achieving research-only positions (including at the highest ranks); however, research-only contracts tend to be fixed-term. This paper considers women's experiences of the temporary nature of research-only contracts at Victoria University of Wellington. It draws on quantitative analysis of human resources data to describe broad gendered patterns of fixed-term academic employment with a particular focus on research-only positions. Material from in-depth semi-structured interviews with female research-only employees is considered to explore the implications that fixed-term contracts have for women's day-to-day working lives, work/life balance and career development.
\end{abstract}

\section{Introduction}

New managerialist management practices are being increasingly applied to the organisation of academic labour across most Western, English speaking countries (Kogan et al. 1994: 23; de Groot 1997; Dearlove 1997; Deem 1998; Meadmore 1998; Miller 1998; Lafferty and Flemming 2000; Blackmore 2002). Techniques include devolution, decentralisation, internal competition, marketisation, strategic planning, orientation to outputs, efficiency performance, monitoring and accountability (Deem 1998: 50; Kimber 2003: 43). A major symptom of new managerialism has been a process of casualisation.

Casualisation refers to the increasing proportions of nonpermanent and part-time employment contracts in comparison with the number of fulltime permanent posts (de Groot 1997: 136; Court 1998: 771). This study was interested in non-permanent employment arrangements. In light of local university staffing policies (Ledgerton 2002: 1; University of Canterbury 2002; Victoria University of Wellington 2003) and international higher education studies (Probert et al. 1998: 82), this study uses the term 'temporary' interchangeably with the overarching term non-permanent, while 'fixed-term' and 'casual' are specific subsets. The former involves having a specified contract termination date and the latter involves being hired for an unspecified period as need arises (Victoria University of Wellington 2003).

Researchers have highlighted a gender dimension to causalisation (Stiver Lie and O'Leary 1990: 25; Asmar 1999: 258). For example, in 1998-1999, only $37 \%$ of women in UK academic positions were permanent, in contrast with $59 \%$ of men (Bryson 2004: 196). New Zealand tertiary staff statistics collected by the Ministry of Education (MoE) do not distinguish between permanent and non-permanent staff. However, a 1998 of Association of University Staff (AUS) survey found that female union members were over three times more likely than male members to be employed on a 'limited-term' academic contract ( $27 \%$ versus $8 \%$ ) (Chalmers 1998: 15$)$.

The implications that fixed-term positions have for women's advancement have been debated. Some commentators have claimed that non-permanent employment could serve as a 'bridge' or 'stepping stone' and facilitate women's access into and upwards within the academy, yet others have argued that such employment is more likely to function as a 'trap' or 'sticking point' heightening women's employment insecurity and vulnerability (Jackson 1990: 322; Bryson 2004: 187; Department of Labour 2004).

In hand with the casualisation of new managerialism there has been a segmentation of traditional teaching-andresearch positions into teaching-only and research-only positions. Research-only contracts tend to be fixed-term (Court 1998: 769; Bryson 1999: 199).

In addition to traditional Postdoctoral Fellowships, new types of research-only positions have also been created, funded by internal contestable funds won by permanent teaching-and-research staff to employ research support staff, or by competitive external grants and contracts from government-funded research councils or individual agencies (Kogan, Moses et al. 1994: 54,58; Hey 2001: 70).

New Zealand growth in research-only positions has been relatively slow in comparison to the UK where 'contract researchers' make up over one third of academic staff (de Groot 1997: 136; Bryson and Barnes 2000: 199). 
According to MoE tertiary staff statistics collected in 2002 research-only positions only account for $14 \%$ of all academic staff in New Zealand.

One potential explanation for slower growth in New Zealand is that the government has only recently introduced tertiary education reforms which include new systems to promote and fund research (Ministry of Education 2003: 107). The two most important initiatives are Centres of Research Excellence Fund (similar to UK's Centres for Excellence in Research) and the Performance Based Research Fund (which shares some similarities with UK's Research Assessment Exercise).

There has been very little discussion around the implications the new funding system has for researchonly staff, despite the fact that many of the developments appear to encourage growth in this type of employment. Research-only employees often develop, secure and staff 'contracted' research projects. In addition the PBRF evaluation requires academic staff to assemble an evidence portfolio (EP) that records their research outputs, peer esteem and contribution to the research environment over the past six years (Ledgerton 2003: 7). Research-only staff above the level of Research Assistant employed within a university for at least one year (or who are on a contract with a duration of at least a year) are 'likely' to be required to take part (Tertiary Education Commission 2003: 3,8).

Considering male to female ratios in the UK, there is a greater proportionate representation of women in research-only positions than in teaching-and-research positions (Aziz 1990: 38; Court 1998: 743). A similar pattern appears in New Zealand. Tertiary staff statistics 2002 demonstrate that the proportion of women staff is higher in the research-only staff category $(56.4 \%)$ than the teaching category $(41.2 \%)$, the latter of which includes teaching-and-research positions plus teachingonly positions. The data does not disaggregate specific research-only grades (such as Research Assistant, Research Fellow, Senior Research Fellow and Postdoctoral Fellow), although there is a higher proportion of women staff in the 'other research-only support staff' than in the 'research-only staff' category.

Overall, fixed-term research-only positions are a product of related shifts towards managerialism and casualisation in the higher education sector. Nevertheless, researchonly and fixed-term positions are largely invisible in New Zealand tertiary statistics, consequently preventing necessary gender analysis. Likewise no local research has explicitly considered the experiences of women in fixed-term research-only positions. This study was intended to address the research lacuna.

\section{The Study}

The study was undertaken in partial fulfilment of an M.A. (Applied) Social Science Research (Roberts 2004). The aim of the research was to explore women's experiences of the temporary nature of research-only contracts at Victoria University of Wellington. A study within the case of Victoria University was appropriate for several reasons. Firstly, such an approach is suitable for exploratory studies. To quote Deem (2002: 167):

when [small scale qualitative] studies are conducted with an awareness of their limitations, they can produce results that, whilst not empirically generalisable, can assist theory development and practical initiatives and provide a useful clearing ground for later projects.

Secondly, research on academic women often considers the situation for women within a single university as an indication of women's situation within the wider national or international higher education environment (for example, Ethington and Pisani 1993; West and Lyon 1995; Deem 1998; Probert, Ewer et al. 1998; Toren and Moore 1998; Bagilhole and Goode 2001). Thirdly, demonstrated discrepancies between employment practices and data collection between universities, particularly in casual and fixed-term employment, suggested that a larger-scale project would not have been manageable (Probert, Ewer et al. 1998: 82; Bryson and Barnes 2000:188-189).

I drew on multiple methods to situate women's qualitative experience within broader quantitative gendered patterns, and conversely to "locate statistics within the authority of women's experiences' (Morley 1994: 195)

I conducted secondary data analysis on a spreadsheet from Victoria's Human Resources Management Information Systems (HRMIS) employment database as at 31 March 2003. I was provided with an Excel spreadsheet that included the sum total of 3290 positions at the university. The data represented positions as opposed to staff numbers since some staff filled more than one position. I methodically followed a removal process so as to be left with only 'academic positions' defined as "employees within the four academic faculties who had teaching and/or research titles, including tutors and research assistants'. I then grouped the multitude of job titles into standard categories.

I interviewed thirteen women research-only staff at Victoria University, recruited via personal networks and snowball sampling. Interviewees were employed across all faculties and within seven schools. Seven women were in a research centre/unit. The length of time interviewees had been employed in research-only positions at Victoria ranged from six months to over ten years. Women's latest research-only contracts ranged from three months to three years in duration. Further demographics were:

- Position: Research Assistant (6), Research Fellow (2), Senior Research Fellow (2), Postdoctoral Fellow (1), Other Researcher (2).

- Fulltime Equivalence across Victoria position(s): Fulltime (7), Nearly fulltime (5), Half-time (1).

- Number of current Victoria positions: single position (8), multiple positions (5). 
- Highest qualification: PhD (2), Masters (6), Bachelors (2), No degree (1).

- Ethnicity: Pakeha/European (10), Mãori (2), Pacific (1).

\section{- Dependents: 9 had children, 4 did not.}

\section{The Numbers}

Two subsets of academic positions (as defined above) were considered, teaching positions and research-only positions. Teaching positions were defined as positions with a job title that indicated teaching responsibilities, including both teaching-and-research staff and teachingonly staff (i.e. from Tutors to Professors). Research-only positions were defined as positions with a job title that indicated research-only responsibilities (i.e. from Research Assistants to Postdoctoral Fellows).

Of the 482 permanent academic positions at Victoria, men filled $65.1 \%$. Looking it at another way $40.1 \%$ of the 783 positions filled by men were permanent, where as $23.6 \%$ of the positions filled by women were permanent. The great majority of permanent positions were fulltime $(94.0 \%)$ where as the great majority of the 841 fixed-term positions were part-time $(90.2 \%)$.

Research-only positions made up $11 \%$ of academic positions at Victoria. Of 1495 academic positions, 1332 were combined teaching-and-research positions or teaching-only positions and 163 were research-only positions. Of the 1332 teaching positions, $36.2 \%$ were permanent, and permanence was more common in the higher ranks. Looking at the two extremes, $0.9 \%$ of tutors were permanent while $96.6 \%$ of senior lecturers were permanent. In contrast, not a single research-only position was permanent regardless of seniority from Research Assistant to Senior Research Fellow. The great majority of research-only positions were fixed-term (139 out of 163) while the remaining 24 positions were casual (all but one being research assistant positions).

The balance between women and men was unique in research-only positions. Teaching positions showed clear vertical gender segregation: the higher the seniority the lower the proportion of women. Research-only positions did not show the same pattern. Women filled the majority at every research-only level. Although numbers were small, the proportion of women actually increased the higher the seniority. The number of positions filled by women was equal or greater to those held by men at every research-only grade within every faculty (with the only exception being research assistant positions in the commerce faculty).

Of the 163 research-only cases, $79.8 \%$ were part-time. Although men and women were equally likely to hold the rare fulltime research-only positions, on average women held part-time positions of a lesser fulltime equivalence (FTE).

In the great majority of positions $(87.1 \%)$, the same research-only employee had been reappointed or 'signed at least two contracts' for the position. Women were over 10 percentage points more likely than men to have signed at least two contracts for the same position. This is perhaps because on average positions (inclusive of any reappointments) filled by women were 45 days longer in duration than positions filled by men. Men signed latest contracts with a longer average duration than women across all research-only job titles except two although the overall difference between the average length of men's and women's contracts was only five days.

In summary, analysis of Victoria's HRMIS data demonstrates that, in comparison to men, women were proportionately better represented in research-only positions than academic positions that involve teaching. A clear difference between the two categories of employment was that research-only positions were exclusively non-permanent and generally part-time.

When looking solely at research-only positions women appeared to be in a similar, if not better, situation than men. Positions held by women were, on average, more numerous, higher in rank, longer in total duration, more likely to be covered by the union and less likely to be casual. Women were just as (un)likely as men to hold a fulltime contract. On the other hand men, on average, signed slightly longer contracts with greater FTE. The data itself does not indicate how women experience such aspects.

\section{The Stories}

The following sections consider women's experiences within their research-only roles. Specifically, I explore issues emerging from the temporary nature of researchonly positions that women face according to four key emergent themes.

\section{Working within Fixed Boundaries}

Research-only work tends to be intellectually stimulating and personally gratifying. However, fixed-term work is also characterised by high pressure.

\section{It is premised around things being shorter term and there being an imperative that stuff gets pumped out ...it gets a bit taxing I've got to say (Senior) Research Fellow, RF).}

Although this may seem to be a reasonable expectation some women made sacrifices in order to achieve requirements and maintain their reputation (and/or their research centre's reputation). Their dates of termination signal to women that a failure to meet high demands could compromise their future employment opportunities.

\footnotetext{
Having your contracts extended all adds up to I think you actually work better...I have to prove that $I$ 'm good enough for another year (Research Assistant, RA)
}

Some women absorbed work into their unpaid time, particularly if their position was part-time. Others felt that being a fixed-term employee discouraged them from 
challenging practices in their workplace that they were unhappy with.

\section{Balancing Contracts Simultaneously and Sequentially}

Six of the women I interviewed had, at some stage, held two or more positions simultaneously.

\section{...I was a tutor for [two] papers and an assistant to $m y$ boss and um the rest of the time as a researcher (RA).}

Two women commented on their enjoyment of teaching but admitted that their ideal employment scenario would be a single long-term research position.

I would just like for someone to say look we're going to offer you um a job at this many thousand dollars a year. come to work 5 days a week, 40 hours a week' (RA)

Attempting to maintain more than one position was often associated with a sense of work overload and competing demands.

\section{I started taking on too much 'cause I thought well it's either going to be like a - you know um a drought situation. where there isn't enough, or there's going to be too much $(R A)$.}

The termination points of fixed-term contracts demand that women move across contracts sequentially - either by signing a new contract for the same position or by moving to a new position under a new manager or new job title.

There seems to be a period of ... a month and half in the middle of each semester that I'm not hunting for work (RA).

Several women expressed frustration with their perceived inability to progress.

\footnotetext{
...it kind of feels like getting the most that thev can out of someone without actually giving them any job security or a kind of foot hold to sort of move up the ranks with it (RA)
}

For most a reappointment was preferable to seeking a new position. Still despite a hope that their position would continue for the near future, interviewees questioned the validity or likelihood of this in light of approaching contract end-dates

\section{... [my manager] said, you know your contract is due to end [in a few months]. And I can't promise you anything after that'. And, you know, that happens every time. Um, and I think, bugger... I'm going to be having to spend time thinking about this and dealing with it $(R F)$.}

Most interviewees commented on the extent, either positively or negatively, to which they believed their manager recognised vulnerabilities associated with fixedterm contracts.

\section{[My manager] does give you a wee bit of warning, you know 'in about a couple of months' [they'll] tell you 'your contract's up but, you know, this is what we've got in the pipeline:. And to me that certainly makes me feel more secure (RA).}

The theme of anxiety was strongest in women's discussions. All interviewees appeared to exert a lot of energy, both psychological and physical, in attempting to mesh together funding sources, contracts and positions simultaneously and/or sequentially over time.

\section{Negotiating Staff Status and Establishing Work Relationships}

The extent to which women felt part of their School or research unit varied widely. Interviewees mentioned a range of exclusionary practices, many of which related to restricted access to material resources or staff networks. Some Schools also support a clear status hierarchy in research-only positions.

...it took me a long, long, long time to realise that I'm not actually a member of staff and I shouldn't go into the staff room, that I'm a student... but bizarrely enough I had the same problem when I went into the student area...they thought that I was a staff member (Research Assistant, RA)

The relationship between research-only positions and teaching-and-research positions appears to be fairly ambiguous. Research Fellows were more likely than Research Assistants to identify as an academic. Those on longer contracts were more likely to feel like "part of the woodwork". However, perceived peripheral status was never ameliorated.

I've always kept myself back a little bit. So I've tended not to bother with things like going to Faculty meetings for instance because I' $m$ not allowed to vote anyway $(R F)$.

Furthermore, women saw a difference between permanent and fixed-term staff working at the same level on a project.

...you're actually expected to develop a proper academic career...to publish, to go to conferences, to develop relationships with research participants and end users and all the while you're doing this knowing that maybe next year the funding won't be renewed... You're in a very different position to people who are permanent staff who are involved in the same project who are doing it from the point from the point of 'Well if we lose the funding, you know we re still paid to do research as part of our academic jobs'. And so it 's quite a different sort of relationship that you have with other people in your department $(R F)$ 
Where research-only staff formed a 'critical mass' (AllenCollinson and Hockey 1998: 505), such as within a reasonably-sized research unit, women were less inclined to view their employment position as negatively impacting on their work relationships or academic status.

\section{Work/life Balance}

Women discussed work/life balance primarily in terms of parenting and study commitments, holidays and financial planning.

Flexibility to balance work with parenting benefited women with children, particularly those who were primary or sole caregivers and those with pre-schoolers. However, women did not attribute this to the temporary nature of their employment. Instead women attributed flexibility to having part-time contracts or flexible work hours.

\section{...I have school holidays off with my kids and you know be home after school and work in the evenings and the weekends to make up the time (RF).}

Some women were supported to study either through having their fees/study time paid for or through flexibility available in their work hours. In contrast, others found balancing study and fixed-term contracts difficult.

\section{...you can't actually concentrate on your part-time study because you're always having to concentrate on sourcing work $(R A)$}

An inability for long-term financial planning was a key concern, since an ongoing source of income beyond a termination date could not be depended on. It prevented some on wages from taking adequate breaks.

\begin{abstract}
...there's a bit of me that is kidding myself when I think oh OK maybe I could take a month off - ah a week off in August... But in reality that hardly ever happens...something comes up and you've just got to go for it because you don't know if anything else is going to be available (Other Researcher, OR).
\end{abstract}

Three women explicitly stated that fixed-term contracts were no longer sustainable, and they were not prepared to continue employment on this basis.

\begin{abstract}
...the short-term contracts I started off with fitted around my study and my priorities and my needs were quite different then to now as a full-time employee on short-term contracts (OR).
\end{abstract}

In general, women have multiple responsibilities in their life. However, fixed-term contracts appear to create as many problems as they solve.

\section{Conclusion}

Research staffing has not come under sustained national attention within New Zealand. According to Bryson (1999: 203-4), some individuals and universities believe that rather than a research-only career structure there should be a career pathway from research-only positions into teaching-and-research positions. The Education Act 1989 characterises universities as institutions where 'research and teaching are closely interdependent and most of their teaching is done by people who are active in advancing knowledge' (Ministry of Education 2003: 107). I suggest that part of the reason research-only staff have been sidelined is because of a tension between academic roles associated with new managerialist principles and those associated with older systems of collegiality. Fixed-term employment provides a way to employ research-only staff within the current funding regime without directly threatening the traditional model of academic research labour being self-regulated, disassociated from economic pressures and intertwined with teaching (de Groot 1997: 131-133; Dearlove 1997: 57; Blackmore 2002: 422).

However, many women in this study reflected international research which suggests research-only staff consider their employment to be a career choice (Youngman 1994; Bryson 1999; Hobson et al. 2002; Allen-Collinson 2003). With regards to career development, longer-term contracts that involve expertise development, leadership roles, and publication visibility, appeared to be amongst the ingredients that could increase 'career' success. At the same time possibilities for a research-only career are compromised by limitedlife contracts and a bottom-heavy research-only hierarchy (Youngman 1994: 392; Pirrie 1997: 570; Bryson 1999: 38; Bryson and Barnes 2000: 203; Hobson, Jones et al. 2002: 1).

The decentralisation and competition of new managerialism appear to have reached a point where research funding and employment have become so compartmentalised that women on fixed-term contracts are bearing the responsibility of organisational coordination. Despite essentially having a single employer, women individually coordinate different positions, projects and grants from different parts of the university and from a wider funding environment. For many each component is represented by a separate contract with an individual date of termination. According to interviewees experiences, there appear to be few organisational strategies in place to protect women research-only staff in 'lean times', nor the organisational coordination available to ensure women's employment is maintained within the university despite a funding dip in one area.

The flexibility the university has in the employment of research staff translates to insecurity for those employed. A number of interviewees described a situation the Employment Relations Act was supposedly designed to avoid - that of rolling fixed-term agreements. When funding is secured women are likely to receive a further contract; when funding is not secured they do not.

A clear drawback for the university is the premature loss of research-only staff. Fixed-term contracts, particularly those that are short-term and part-time, are associated with high pressure and anxiety, which can eventually encourage women to leave. Women are also effectively forced to seek an alternative employer when external 
funding is not secured for a short period of time. Although more funding may be available at a later date, or in a complementary discipline, these skilled researchers and topic experts, who have been trained onthe-job within the university, will have already moved on.

Recent policy developments, such as New Zealand's Performance Based Research Fund, signal that it is an ideal time for universities to seriously consider the use of fixed-term contracts in research-only employment. Women's experiences highlight a wide range of personal and professional sacrifices emerging from the temporary nature of their contracts as well as pointing to negative implications for the university at large. A reconsideration of current practices could ultimately lead towards greater employment equity, superior research capacity, and - in the powerful words of new managerialism - enhanced income generation.

\section{Future Research}

This study took into account a policy backdrop and employment data while exploring women's experience via interview material. However, it did not take into account further people and processes. A larger scale research project might include the perspectives of managers, administrators and government officials to examine how women's experiences are structured by outside forces (see Smith 1990 in DeVault 1990). Alternatively future research might consider issues raised in this exploratory study to test against a representative national sample of research-only or fixed-term staff.

\section{References}

Allen-Collinson, J. (2003). Working at a marginal 'career': the case of UK social science contract researchers. The Sociological Review, 51, 3, 405 422.

Allen-Collinson, J. and Hockey, J. (1998). Capturing contracts: informal activity among contract researchers. British Journal of Sociology of Education, 19, 4, 497-515.

Asmar, C. (1999). Is there a gendered agenda in academia? The research experience of female and male $\mathrm{PhD}$ graduates in Australian universities. Higher Education, 38, 255-273.

Aziz, A. (1990). Women in UK universities: the road to casualisation? Lie, S. S. and O'Leary, V. E. (Eds.) Storming the Tower: Women in the Academic World. London: Kogan Page Ltd.

Bagilhole, B. and Goode, J. (2001). The contradiction of the myth of individual merit, and the reality of a patriarchal support system in academic careers. The European Journal of Women's Studies, 8, 2, 161-180.

Blackmore, J. (2002). Globalisation and the restructuring of higher education for new knowledge economies: new dangers or old habits troubling gender equity work in universities. Higher Education Quarterly, 56, 4, 419-441.

Bryson, C. (1999). Contract research: the failure to address the real issues. Higher Education Review, 31, 2, 29-49.

Bryson, C. (2004). The consequences for women in the academic profession of the widespread use of fixed term contracts. Gender, Work and Organisation, 11, 2, 187-206.

Bryson, C. and Barnes, N. (2000). The casualisation of employment in higher education in the United Kingdom. Tight, M. (Ed.) Academic Work and Life: What It Is To Be An Academic, and How This Is Changing. New York: Elsevier Science.

Chalmers, A. (1998). Workload and Stress in New Zealand Universities in 1998: A Follow-up to the 1994 Study. Wellington: New Zealand Council for Educational Research \& Association of University Staff New Zealand.

Court, S. (1998). Academic tenure and employment in the UK. Sociological Perspectives, 41, 4, 767-781.

de Groot, J. (1997). After the ivory tower: gender, commodification and the 'academic'. Feminist Review, 55, 130-142.

Dearlove, J. (1997). The academic labour process: from collegiality to professionalism to managerialism and proletarianisation? Higher Education Review, 30, 1, 56-75.

Deem, R. (1998). 'New managerialism' and higher education: the management of performances and cultures in universities in the United Kingdom. International Studies in Sociology of Education, 8, 1, 47-70.

Deem, R. (2002). Talking to manager-academics: methodological dilemmas and feminist research strategies. Sociology, 36, 4, 835-859.

Department of Labour (2004). 'Precarious' Nonstandard work - what is it?, Department of Labour. http://www.dol.govt.nz/futureofwork/workplaceprecarious.asp Accessed: 15 January 2004.

DeVault, M. L. (1990). Talking and listening from women's standpoint: feminist strategies for interviewing and analysis. Social Problems, 37, 1, 96-116.

Ethington, C. A. and Pisani, A. (1993). The RA and TA experience: impediments and benefits of graduate study. Research in Higher Education, 34, 3, 343354.

Hey, V. (2001). The construction of academic time: sub/contracting academic labour in research. Journal of Education Policy, 16, 1, 67 - 84. 
Hobson, J., Jones, G. and Deane, E. Rewriting the 'research assistant' in an era of innovation and knowledge. Unpublished paper sent by first author. 2002.

Jackson, D. F. (1990), Women working in higher education: a review of the position of women in higher education and policy developments. Higher Education Quarterly, 44, 4, 297-324.

Kimber, M. (2003). The tenured 'core' and the tenuous 'periphery': the casualisation of academic work in Australian universities. Journal of Higher Education Policy and Management, 25, 1, 41-50.

Kogan, M., Moses, I. and El-Khawas, E. (1994). Staffing Higher Education: Meeting New Challenges. London: Jessie Kingsley Publishers.

Lafferty, G. and Flemming, J. (2000). The restructuring of academic work in Australia: Power, management and gender. British Journal of Sociology of Education, 21, 2, 257-267.

Ledgerton, M. Casualisation of University Employment Unpublished discussion paper for the AUS Council, May 2002.

Ledgerton, M. (2003). Performance Based Research Fund Lift Out. AUS Bulletin. 57: 5-12.

Meadmore, D. (1998). Changing the culture: the governance of the Australian pre-millennial university. International Studies in Sociology of Education, 8, 1, 27-45.

Miller, H. (1998). Managing academics in Canada and the United Kingdom. International Studies in Sociology of Education, 8, 1, 3-25.

Ministry of Education. New Zealand's Tertiary Education Sector Report: Profile and Trends 2002. Wellington: Ministry of Education, December 2003.

Morley, L. (1994). Glass ceiling or iron cage: women in UK academia. Gender, Work and Organisation, 1, 4, 194-204.
Pirrie, A. (1997). The new game: professional foul or own goal. British Educational Research Journal, 23, 5, 565-574.

Probert, B., Ewer, P. and Whiting, K. (1998). Gender Pay Equity in Australian Higher Education. Melbourne: National Tertiary Education Union.

Roberts, J. M. Precariously perched: Women's experiences of the temporary nature of researchonly contracts at Victoria University of Wellington. Wellington: Victoria University of Wellington, March 2004.

Stiver Lie, S. and O'Leary, V. E., Eds. (1990). Storming the Tower: Women in the Academic World. London: Kogan Page Ltd.

Tertiary Education Commission. Performance Based Research Fund - Quality Evaluation: Staff Participation Guidelines. Wellington: Tertiary Education Commission, 19 March 2003.

Toren, N. and Moore, D. (1998). The academic "hurdle race": A case study. Higher Education, 35, $267-$ 283.

University of Canterbury (2002). Academic and General: Recruitment of Fixed-Term and Casual Employees, University of Canterbury. http://www.canterbury.ac.nz/hr/policy/Recruitmen t/FixedtermandCasualEmployees.pdf Accessed: 13 September 2003.

Victoria University of Wellington (2003). HR Toolkit: Recruitment Policies. http://www.vuw.ac.nz/hr /recruit/policies.htm Accessed: 6 April 2003.

West, J. and Lyon, K. (1995). The trouble with equal opportunities: the case of women academics. Gender and Education, 7, 1, 51-68.

Youngman, M. (1994). Career experiences of contract researchers in education. Research Papers in Education, 9, 369-410. 